\title{
Host Range, Purification, and Genetic Variability in Sweet potato chlorotic fleck virus
}

\author{
V. Aritua, Julius Kuehn Institute, Federal Research Centre for Cultivated Plants (JKI), Institute of Epidemiology and \\ Pathogen Diagnostics, Braunschweig, Germany; National Agricultural Biotechnology Center, Kawanda Agricultural \\ Research Institute, Kampala, Uganda; and Department of Plant Pathology, Kansas State University, Manhattan \\ 66506 USA; E. Barg, JKI, Germany; E. Adipala, Department of Crop Science, Makerere University, Uganda; \\ R. W. Gibson, University of Greenwich, Central Avenue, Chatham Maritime, Kent, ME4 4TB, UK; and \\ D. E. Lesemann and H. J. Vetten, JKI, Germany
}

\begin{abstract}
Aritua, V., Barg, E., Adipala, E., Gibson, R. W., Lesemann, D. E., and Vetten, H. J. 2009. Host range, purification, and genetic variability in Sweet potato chlorotic fleck virus. Plant Dis. 93:8793.

Sweet potato chlorotic fleck virus (SPCFV) has recently been classified as a putative new member of the genus Carlavirus (family Flexiviridae) on the basis of its molecular properties. In this study, SPCFV was characterized in terms of host range, physical and biological characteristics, and genetic variability. In addition to sweet potato, SPCFV infected some plant species in the families Convolvulaceae, Chenopodiaceae, and Solanaceae. Limited numbers of virus particles were observed in the assimilation parenchyma cells of infected plant tissues; some cells had a distorted and enlarged endoplasmic reticulum though without any cytoplasmic and amorphous inclusions. The normal length of SPCFV particles was determined to be approximately $800 \mathrm{~nm}$. In enzyme-linked immunosorbent assays, polyclonal antibodies raised against purified SPCFV virions were able to detect the virus in infected sweet potato and indicator plant tissues. In immunoelectron microscopy, SPCFV particles were all strongly decorated when reacted with homologous antiserum. Comparison of the $3^{\prime}$ terminal part of the genome of a range of geographically diverse isolates revealed a high level of genetic diversity. The amino acid sequence identity in the coat protein and the nucleic acid binding protein ranged from 89 to $99.7 \%$ and from 75.9 to $99.2 \%$, respectively. Phylogenetic analysis of both proteins showed a geographically associated clustering into two genogroups.
\end{abstract}

Sweet potato chlorotic fleck virus (SPCFV), also referred to as sweet potato symptomless virus in Japan due to its symptomless nature of infection in local genotypes, and as C-2 (7), is one of several viruses naturally infecting sweet potato (15). It appeared to be unrelated serologically to other filamentous viruses infecting sweet potato, including Sweet potato feathery mottle virus, Sweet potato virus $G$, and Sweet potato latent virus (genus Potyvirus, family Potyviridae); Sweet potato mild mottle virus (SPMMV, genus Ipomovirus, family Potyviridae); Sweet potato chlorotic stunt virus (genus Crinivirus, family Closteroviridae); and the C-6 virus. Early electron microscopic measurements indicated

Corresponding author: V. Aritua

E-mail: arituavalentine@yahoo.com

varitua@k-state.edu

Sequences published in this article have been assigned GenBank/EMBL/DDBJ database accession numbers EU375897 to 375910 .

Accepted for publication 30 September 2008.

doi:10.1094/PDIS-93-1-0087

(C) 2009 The American Phytopathological Society that SPCFV has filamentous particles of 750 to 800 by $12 \mathrm{~nm}$ in size, and analysis of purified virions by sodium dodecyl sulfate polyacrylamide gel electrophoresis (SDS-PAGE) revealed a capsid protein with a size of $\mathrm{M}_{\mathrm{r}} 33.5 \mathrm{kDa}(7,15)$. However, SPCFV remained unclassified until complete sequencing of a Ugandan isolate of SPCFV revealed that it has a singlestranded, positive-sense RNA genome consisting of 9,104 nucleotides (nt) containing six putative open reading frames (ORFs) and sharing highest nucleotide and amino acid sequence similarities with viruses of the genus Carlavirus in the family Flexiviridae (4). The closest relative of SPCFV is Melon yellowing-associated virus (MYaV), a whitely-transmitted carlavirus from Brazil (25), with which it shares ORF5 and ORF6 amino acid sequence similarities of 61 and $46 \%$, respectively.

Previous serological tests of sweet potato crops demonstrated that SPCFV has a wide geographic distribution, occurring in Brazil, Bolivia, China, Colombia, Cuba, Indonesia, Japan, Panama, Peru, Philippines $(8,15,28)$, Kenya (6), Tanzania (29), and Uganda $(5,24)$. In the three East African countries, SPCFV was the fourth most common virus, infecting about 5\% (24) to $8 \%$ (5) of diseased plants in Uganda, about $3 \%$ of diseased plants in Kenya (6), and was rarely (just five plants) found in the Lake Zone of Tanzania (29). SPCFV has a narrow host range previously considered to be restricted to a few members of the Convolvulaceae and Chenopodiaceae families $(7,15)$; our study extends its known experimental host range. In addition to conducting further measurements of the particle length and attempts at studying possible cytopathic effects in SPCFV-infected tissue, we have produced a specific antiserum. The extent of genetic variability among a range of geographically diverse isolates was also established for two sections of their 3 '-terminal genomic regions.

\section{MATERIALS AND METHODS}

Sources and maintenance of virus isolates. The SPCFV isolates used in this study originated from geographically distant regions of the world, including Uganda, Kenya, Tanzania, Peru, Taiwan, and China, or were of unknown geographic origin (Table 1). All SPCFV-infected samples from Uganda and some from Kenya were collected in the course of this study $(5,6)$. Most isolates were subcultured every 2 to 3 months by sap inoculation to Nicotiana occidentalis subsp. obliqua but Guangzhou 1 was maintained in the original sweet potato plant. Isolate Rukingiri 1a was maintained as a mixed infection with SPMMV in $N$. occidentalis 'P1' while SPCFV-CIP was obtained from the International Potato Center (CIP) in a dried leaf sample of Ipomoea nil.

Experimental host range. The susceptibility to SPCFV of the following test plants was examined by inoculation with isolate Hoima 4: family Solanaceae: $D a$ tura stramonium, $N$. benthamiana, $N$. clevelandii, $N$. glutinosa, $N$. hesperis, $N$. occidentalis subsp. obliqua, N. occidentalis $\mathrm{P} 1, N$. rustica, $N$. sylvestris, $N$. tabacum 'Xanthi', N. tabacum 'Samsun NN', Physalis floridana, and Solanum demissum; family Convolvulaceae: I. setosa, I. nil, I. purpurea, I. aquatica, I. coccinea, and I. wrightii; and family Chenopodiaceae: Chenopodium amaranticolor, $C$. murale, and $C$. quinoa. To confirm sus- 
ceptibilities, seven further SPCFV isolates (Hoima 3c, KBL38, Mpigi 6b, Kiboga 6b, TN340, Le-97-589, and 94/1S; Table 1) were inoculated to susceptible test plants using leaf extracts from SPCFV-infected N. occidentalis subsp. obliqua. Plants were inoculated at the two- to five-true leaf growth stage for Ipomoea spp. and five- to eight-leaf growth stage for the others. The inoculated plants and an uninoculated plant for each test plant species were grown in a sterilized Floradur-sand mixture $(1: 1, \mathrm{wt} / \mathrm{vol})$ (Floragard Vertriebs $\mathrm{GmbH}$, Oldenburg, Germany) in an insectfree greenhouse at 20 to $25^{\circ} \mathrm{C}$ under a 12 to $16-\mathrm{h}$ photoperiod. Plants were observed for symptom development every 2 to 3 days for a period of up to 2 months. Inoculated and top leaves from all plants were individually assayed for the presence of SPCFV in double-antibody sandwich enzyme-linked immunosorbent assays (DASELISAs; 10) and immunosorbent electron microscopy (ISEM; 23) using the SPCFV antiserum previously raised at $\operatorname{CIP}(8,15)$ or that produced in this study. Infections were further confirmed by back inoculations onto $N$. occidentalis subsp. obliqua.

Virus purification, serology, and cytopathological studies. Two isolates of SPCFV, Hoima 4 and TN340, were purified from infected leaves of $N$. occidentalis subsp. obliqua using a modification of the procedure outlined by Vetten et al. (31). Briefly, $200 \mathrm{~g}$ of leaves were harvested 18 to 42 days after inoculation and homogenized in two volumes (wt/vol) of chilled $\left(4^{\circ} \mathrm{C}\right) 0.5 \mathrm{M} \mathrm{K}_{2} \mathrm{HPO}_{4}$ buffer, $\mathrm{pH} 8.5$, containing $0.02 \mathrm{M}$ (wt/vol) $\mathrm{Na}_{2} \mathrm{SO}_{3}, 0.01 \mathrm{M}$ DIECA, and $0.005 \mathrm{M}$ EDTA. Chloroform (10\%) was added and homogenized briefly, and the homogenate clarified at $8,000 \mathrm{rpm}$ for $15 \mathrm{~min}$ in a Sorvall GSA rotor. The aqueous phase was filtered and centrifuged at $20,000 \mathrm{rpm}$ for $2 \mathrm{~h}$ at $10^{\circ} \mathrm{C}$ in a Beckman Ti45 rotor. The pellet was resuspended in $1 \mathrm{ml}$ of $0.05 \mathrm{M}$ sodium citrate buffer ( $\mathrm{pH} 7.5)$ and the virus particles twice purified by isopycnic centrifuga- tion in $\mathrm{CsCl}(400 \mathrm{mg} / \mathrm{ml})$ at $35,000 \mathrm{rpm}$ for 18 to $20 \mathrm{~h}$ at $10^{\circ} \mathrm{C}$ in a Beckman SW55Ti rotor. Virion preparations were examined for purity and homogeneity by electron microscopy and analyzed by UV spectrophotometry using a Hitachi U-3200 spectrophotometer and an extinction coefficient of 2.8 to calculate the virus yield (26). The purified virus was used for antiserum production, analysis of coat protein (CP) properties and RNA isolation for cDNA synthesis, cloning, and sequencing.

For raising an antiserum to both Hoima 4 and TN340, rabbits were immunized as described earlier by Vetten et al. (31). Immunoglobulin $\mathrm{G}$ (IgG) was isolated from the serum and labeled with alkaline phosphatase (AP) for use in DAS-ELISA as described (10).

Mean particle length of SPCFV was determined from fresh leaf extracts using the IgG in ISEM to trap sufficient numbers of virions (23). Lengths of about 100 particles were measured at a magnification of $\times 50,000$ in a Zeiss EM 906 transmission electron microscope with an online attached image analyzing system (Digivision, SIS, Muenster, Germany) for histogram production and normal length calculation. The cytopathological effects induced by SPCFV were studied as described by Koenig and Lesemann (19) using systemically infected leaves collected 2 to 3 weeks after mechanical inoculation of $N$. occidentalis subsp. obliqua seedlings with the isolates TN340 and Hoima 4. This was done in two separate experiments and included leaves from noninoculated $N$. occidentalis as control plants. Ultrathin sections were made using an ultramicrotome (LKB Ultramicrotome III) and viewed and photographed in a Zeiss EM 906 electron microscope.

Reverse-transcription polymerase chain reaction. Apart from SPCFV-CIP, for which a dried sample was used, total RNA was extracted from fresh leaf tissues using the Silica Capture method (21) modified by Rott and Jelkmann (27). Comple- mentary DNA (cDNA) was synthesized from the polyadenylated RNA using RevertAid Moloney murine leukaemia virus reverse transcriptase (MMuLV-RT; Promega Corp., Madison, WI) with an oligo(dT) 18 primer (Table 2) following the manufacturer's recommendations. Polymerase chain reaction (PCR) was then performed using SPCFVuniUp1 (Table 2) and oligo $(\mathrm{dT})_{18}$ as the sense and antisense primers, respectively, and a mixture of a high proof reading DNA polymerase (Proof sprinter Taq/Pwo Mix; HYBAID-AGS, Germany). The primer SPCFVuniUp1 was from the complete genome sequence of the SPCFV isolate Hoima 4 (4; GenBank accession no. AY461421). The PCR amplification reaction $(50 \mu \mathrm{l})$ contained $5 \%$ dimethyl sulfoxide (DMSO), $2.0 \mu \mathrm{l}$ of cDNA, $0.5 \mu \mathrm{l}$ of Tween 20 (10\%), $5 \mu \mathrm{l}$ of $10 \times$ PCR buffer (Gibco, BRL), $0.4 \mu$ of dNTP (25 mM each), $0.5 \mu \mathrm{l}$ of Taq/Pwo $\operatorname{Mix}(5 \mathrm{U} / \mu \mathrm{l})$, and $0.5 \mu \mathrm{l}(100 \mathrm{pmol})$ each of the sense and antisense primers. The following thermal cycling parameters were used: initial denaturation at $94^{\circ} \mathrm{C}$ for $4 \mathrm{~min}$ followed by 29 cycles of denaturation at $94^{\circ} \mathrm{C}$ for $30 \mathrm{~s}$, primer annealing at $55^{\circ} \mathrm{C}$ for $1 \mathrm{~min}$, and DNA extension at $72^{\circ} \mathrm{C}$ for $50 \mathrm{~s}$. The final extension step was at $72^{\circ} \mathrm{C}$ for $7 \mathrm{~min}$.

Random PCR. To generate sequences from isolates that could not be amplified by the SPCFVuniUp1/oligo(dT) $)_{18}$ primer combination, the Random PCR method (14) was used. Viral genomic RNA was extracted from the purified virions of isolate TN340 using the NucleoSpin RNA Plant kit (Macherey-Nagel GmbH \& Co., Germany), followed by cDNA synthesis and amplification of genomic fragments using the Random PCR. First-strand cDNA was synthesized using a universal primer$\mathrm{dN}_{6}$ (UN-RH; Table 2) and MMuLV-RT according to the manufacturer's instructions. RNase $\mathrm{H}^{-}$(Promega Corp.) was included in the reaction to remove unincorporated RNAs. The second strand was synthesized using Klenow DNA poly-

Table 1. Origin of and sequence data on Sweet potato chlorotic fleck virus (SPCFV) isolates included in this study

\begin{tabular}{|c|c|c|c|c|}
\hline \multirow[b]{2}{*}{ Isolate } & \multicolumn{2}{|r|}{ Source } & \multicolumn{2}{|c|}{ Sequence data } \\
\hline & Country of origin & Provided by & GenBank accession no. & Reference \\
\hline Guangzhou 1 & China & D. Colinet, Gembloux, Belgium & EU375901 & This study \\
\hline Hoima 3c & Uganda & 4 & EU375902 & This study \\
\hline Hoima 4 & Uganda & 4 & AY461421 & 5 \\
\hline KBL38 & Uganda & 4 & EU375903 & This study \\
\hline KY5 & Kenya & Stock of JKI, Braunschweig, Germany & EU375904 & This study \\
\hline Kiboga $6 b$ & Uganda & 4 & EU375908 & This study \\
\hline Le-97-598 & Unknown & Stock of JKI, Braunschweig, Germany & EU375905 & This study \\
\hline Mas & Uganda & Not applicable & AJ781295 & Mukasa et al. (unpublished) \\
\hline Mpigi 6b & Uganda & 4 & EU375906 & This study \\
\hline Njoro 2 & Kenya & Stock of JKI, Braunschweig, Germany & EU375910 & This study \\
\hline Rukingiri 1a & Uganda & 4 & EU375907 & This study \\
\hline SPCFV-CIP & Peru & L.F. Salazar, CIP, Lima, Peru & EU375899 & This study \\
\hline Tar & Tanzania & Not applicable & AJ781296 & Mukasa et al. (unpublished) \\
\hline TN340 & Taiwan & S.K. Green, AVRDC, Taiwan & EU375898 & This study \\
\hline TN399 & Unknown & S.K. Green, AVRDC, Taiwan & EU375909 & This study \\
\hline 007VIIMS & Unknown & Stock of JKI, Braunschweig, Germany & EU375897 & This study \\
\hline $94 / 1 \mathrm{~S}$ & Kenya & E. Ateka, Nairobi, Kenya & EU375900 & This study \\
\hline
\end{tabular}


merase (Promega Corp.) according to the manufacturer's instructions. PCR was then performed in the same reaction mix as for the reverse-transcription (RT)-PCR using $\mathrm{Taq}$ polymerase and the universal primer, Random-UN (Table 2), under the following thermal cycling conditions: preliminary denaturing for $2 \mathrm{~min}$ at $94^{\circ} \mathrm{C}$; followed by 29 cycles of $1 \mathrm{~min}$ at $94^{\circ} \mathrm{C}, 1$ min at $60^{\circ} \mathrm{C}$, and $3 \mathrm{~min}$ at $72^{\circ} \mathrm{C}$; and a 5 min final extension at $72^{\circ} \mathrm{C}$. After obtaining initial sequence information from viral clones, isolate-specific primers were designed for RT-PCR and used in combination with oligo $(\mathrm{dT})_{18}$ or another specific primer to clone the remaining unknown parts of the 3 '-terminal regions.

Cloning and sequence analysis. PCR products were analyzed by electrophoresis in an ethidium bromide-stained $(1 \mu \mathrm{g} / \mathrm{ml})$ $1 \%$ agarose gel and purified using the NucleoSpin Extract kit (Macherey-Nagel $\mathrm{GmbH} \&$ Co.). DNA fragments were ligated into the multiple cloning site of pGEM-T vector (Promega Corp.) and cloned in competent cells of Escherichia coli strain DH5 $\alpha$ (Promega Corp.). Plasmid DNA was purified from bacterial cells using the NucleoSpin Plasmid kit (Macherey-Nagel GmbH \& Co.) and the insert was bidirectionally sequenced at MWGBiotech, Ebersberg, Germany. Percent nucleic acid and amino acid sequence identities were generated using DNAMAN (version 4.02; Lynnon Biosoft, Canada). Following multiple pairwise sequence alignments using Clustal V (17) within MEGALIGN package (DNAstar Inc.), nucleic acid sequence distances were estimated using the algorithm of Jukes and Cantor (18), taking into account all positions and all omissions and deletions. Before phylogeny construction, tree topology was inferred using the neighbor-joining algorithm and confidence values for the grouping from the multiple alignments were derived using 1,000 bootstrapped data sets (30). Rooted clustering trees were then drawn and visualized using TREE$\mathrm{CON}$ version $1.3 \mathrm{~b}$ and $\mathrm{MYaV}$, the closest carlavirus relative of SPCFV (4), as an outgroup sequence. The database sequences of the SPCFV isolates Mas from Uganda, Tar from Tanzania (S. B. Mukasa, unpublished), and Hoima 4 from Uganda (4) were included in the comparison.

\section{RESULTS}

Host range. In sweet potato, SPCFV infection was symptomless except for the development of slight veinal flecks in sweet potato cv. Zapallo. Following mechanical inoculation with the SPCFV isolate Hoima 4, symptoms were also observed in several species of the families Convolvulaceae, Chenopodiaceae, and Solanaceae (Table 3). SPCFV isolate Hoima 4 did not infect $D$. stramonium, $N$. clevelandii, N. glutinosa, N. rustica, $N$. sylvestris, $N$. tabacum Xanthi, N. tabacum Samsun NN, and $P$. floridana. Only local lesions were observed in Chenopodium spp. whereas both local and systemic symptoms were observed in most Nicotiana spp. and in four of the six Ipomoea spp. tested (I. nil, I. coccinea, I. setosa, and I. wrightii; Table 3), some showing unique and severe symptoms. Thus, in $I$.

Table 3. Test plant reactions to mechanical inoculation with Sweet potato chlorotic fleck virus isolate Hoima 4

\begin{tabular}{|c|c|c|}
\hline \multirow[b]{2}{*}{ Family, species } & \multicolumn{2}{|c|}{ Type of infectiona } \\
\hline & Local & Systemic \\
\hline \multicolumn{3}{|l|}{ Convolvulaceae } \\
\hline Ipomoea aquatica & - & + \\
\hline I. coccinea & CS & $\mathrm{VC}, \mathrm{M}, \mathrm{LN}$ \\
\hline I. nil & $\mathrm{CS}, \mathrm{nLL}$ & VM, LN \\
\hline I. purpurea & - & + \\
\hline I. setosa & $\mathrm{CS}, \mathrm{nLL}$ & $\mathrm{VC}, \mathrm{M}, \mathrm{LN}$ \\
\hline I. wrightii & $\mathrm{CS}$ & $\mathrm{VC}, \mathrm{M}$ \\
\hline \multicolumn{3}{|l|}{ Chenopodiaceae } \\
\hline Chenopodium amaranticolor & $\mathrm{cLL}, \mathrm{nLL}$ & - \\
\hline C. murale & $\mathrm{cLL}, \mathrm{nLL}$ & - \\
\hline C. quinoa & $\mathrm{cLL}, \mathrm{nLL}$ & - \\
\hline \multicolumn{3}{|l|}{ Solanaceae } \\
\hline Nicotiana benthamiana & - & LY \\
\hline N. hesperis & $\mathrm{CS}$ & VC, M, LD \\
\hline N. occidentalis subsp. obliqua & $\mathrm{CS}$ & VC, LD, St, LN \\
\hline N. occidentalis $\mathrm{P} 1$ & $\mathrm{CS}$ & $\mathrm{VC}, \mathrm{LD}, \mathrm{St}, \mathrm{LN}$ \\
\hline Solanum demissum & $\mathrm{CS}$ & $\mathrm{VC}, \mathrm{M}$ \\
\hline
\end{tabular}

a Abbreviations: - = no symptoms and negative in double-antibody sandwich enzyme-linked immunosorbent assay (DAS-ELISA), $+=$ no symptoms but positive in DAS-ELISA and back inoculation to $N$. occidentalis, $\mathrm{cLL}=$ chlorotic local lesions, $\mathrm{CS}=$ chlorotic spots, $\mathrm{LD}=$ leaf distortion, $\mathrm{LN}=$ leaf necrosis, $\mathrm{LY}=$ leaf yellowing, $\mathrm{M}=$ mosaic, $\mathrm{nLL}=$ necrotic local lesions, $\mathrm{St}=$ stunting, $\mathrm{VC}=$ vein clearing, and $\mathrm{VM}=$ veinal mottle.

Table 2. Primers used to amplify the $3^{\prime}$-terminal genomic regions of Sweet potato chlorotic fleck virus (SPCFV) isolates

\begin{tabular}{|c|c|c|c|c|c|}
\hline Isolate & Orientation & Primer designation & Sequence $\left(5^{\prime}-3^{\prime}\right)$ & $\begin{array}{l}\text { Genomic } \\
\text { position }^{\mathrm{a}}\end{array}$ & $\underset{\text { (nt) }}{\text { Amplicon size }}$ \\
\hline \multirow[t]{2}{*}{ All isolates ${ }^{b}$} & Sense & SPCFVuniUp1 & GCTTGTATGCCACCGCTGT & $7,325-7,343$ & 1,761 \\
\hline & Antisense & Oligo $(\mathrm{dT})_{18}$ & GCGGGATCCTTTTTTTTTTTTTTTTTTTT & & \\
\hline \multirow[t]{4}{*}{ KY 5} & 1.Sense & Hoima4TGBup1 & CGAAGGAGGCTGATACAATG & $7,775-7,794$ & 1,310 \\
\hline & 1.Antisense & Oligo $(\mathrm{dT})_{18}$ & & & \\
\hline & 2.Sense & SPCFVuniUp1 & GCTTGTATGCCACCGCTGT & $8,084-8,102$ & 742 \\
\hline & 2.Antisense & KY5CPlo & TGCAATGCTTTGACTAACGG & $\ldots$ & $\ldots$ \\
\hline \multirow[t]{8}{*}{ TN340 } & 1.RT & UN-RH & GCCGGAGCTCTGCAGAATTCNNNNNN" & $\ldots$ & - \\
\hline & 2.Sense and antisense & Random-UN & GCCGGAGCTCTGCAGAATTC & . & $400-800$ \\
\hline & 3.Sense & TN340CPup1 & CGGTTAGCCAGAGTATTGCCA & $8,339-8,358$ & 745 \\
\hline & 3.Antisense & Oligo $(\mathrm{dT})_{18}$ & & & \\
\hline & 4.Sense & TN340TGB2up1 & GCGCTTGATGGTCTTAGGGA & $7,861-7,880$ & 370 \\
\hline & 4.Antisense & TN340CPlo1 & CGGAAATCCACATCTCCCTCA & $8,250-8,270$ & \\
\hline & 5.Sense & TN340TGBup2 & GTCACCACCAGATCCACATCTG & $7,113-7,133$ & 763 \\
\hline & 5.Antisense & TN340CPlo2 & TGTTGATGGGAAAATCTCGCCC & $7,896-7,916$ & \\
\hline \multirow[t]{6}{*}{ 007VIIMS } & 1.Sense & TN340CPup1 & CGGTTAGCCAGAGTATTGCCA & $8,339-8,358$ & 745 \\
\hline & 1.Antisense & Oligo $(\mathrm{dT})_{18}$ & & & \\
\hline & 2.Sense & TN340TGB2up1 & GCGCTTGATGGTCTTAGGGA & $7,861-7,880$ & 370 \\
\hline & 2.Antisense & TN340CPlo1 & CGGAAATCCACATCTCССТCA & $8,250-8,270$ & \\
\hline & 3.Sense & 007VIIMSTGB2up1 & ACCCATATG(C or T)CA(A or C)CGCTGT & $7,327-7,345$ & 1,081 \\
\hline & 3.Antisense & 007VIIMScplo1 & ATTTAGCGTTCTCAGGAAAGC & $8,426-8,446$ & $\ldots$ \\
\hline
\end{tabular}

${ }^{a}$ Nucleotide (nt) positions relative to the complete genome sequence of SPCFV isolate Hoima 4 (GenBank accession no. AY461421).

${ }^{\mathrm{b}}$ All isolates listed in Table 1 except KY5, TN340, and 007VIIMS.

${ }^{c} \mathrm{~N}=\mathrm{A} / \mathrm{T} / \mathrm{C} / \mathrm{G}$. 
setosa, the first two to three leaves above the inoculated leaves showed conspicuous vein clearing, sometimes with small chlorotic spots, followed by progressive necrosis and leaf shedding. Subsequent leaves were, however, symptomless and tested negative or gave weaker ELISA reactions than symptomatic leaves, indicating lower SPCFV concentrations and a recovery mechanism. In $N$. occidentalis subsp. obliqua, symptoms were fully systemic. Whereas it took 5 to 10 days after inoculation for the development of local lesions on the susceptible species, systemic symptoms became visible 7 to 20 days

M

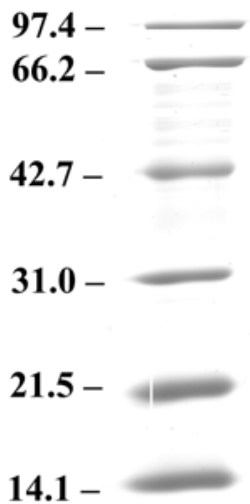

Fig. 1. Sodium dodecyl sulfate page analysis of the caspid protein size of Sweet potato chlorotic fleck virus isolate Hoima 4 (lane 1). M contains the protein size markers, the molecular weights of which are indicated on the left in kilodaltons. after inoculation. The eight SPCFV isolates (Hoima 4, Hoima 3c, KBL 38, Mpigi 6b, Kiboga 6b, TN340, Le-97-589, and 94/1S) induced similar symptoms on the following selected susceptible plants that were tested: $N$. occidentalis subsp. obliqua, N. occidentalis $\mathrm{P} 1, N$. benthamiana, $I$. nil, I. purpurea, I. setosa, I. wrightii, $C$. quinoa, and $C$. murale, whereas 94/1S induced slightly more severe symptoms on $N$. hesperis than other isolates.

Virion purification, particle properties, and cytopathological effects. Using the purification method described above, pure preparations of SPCFV virions essentially free of host contaminants were obtained, as assessed by electron microscopy (EM) and SDS-PAGE. The purified preparations had UV absorption spectra typical of nucleoprotein with a maximum at 260 $\mathrm{nm}$ and a minimum at about 246. Virus yields averaged $30 \mathrm{mg} / \mathrm{kg}$ of tissue after $\mathrm{CsCl}$ density gradient centrifugation, with an absorbance at 260/280 $\mathrm{nm}$ ratio of 1.17 (uncorrected for light scattering). EM examination of the purified virus preparations revealed the presence of long, slightly flexuous rods ranging from 575 to $900 \mathrm{~nm}$ in length. The particles tended to aggregate and exhibited a faint cross-banding similar to that of carlaviruses but were more similar to potyviruses in their length. SDS-PAGE analysis of purified virion preparations revealed one major band which, by comparison with the mobilities of standard proteins, indicated a CP size of $33 \mathrm{kDa}$ (Fig. 1).

Measurements of SPCFV particles in fresh leaf extracts from infected $N$. occi- dentalis subsp. obliqua showed that the filamentous SPCFV particles were about $12 \mathrm{~nm}$ in diameter, consistent with observations by Fuentes and Salazar (15). The normal length of particles was about 760 to 830 and 760 to $860 \mathrm{~nm}$ for Hoima 4 and TN340, respectively. Examination of ultrathin sections of infected $N$. occidentalis subsp. obliqua leaves revealed a few filamentous virus particles in the assimilation parenchyma cells (Fig. 2). In addition, some cells had a distorted and enlarged endoplasmic reticulum (Fig. 2). Cytoplasmic and amorphous inclusion bodies characteristic of Potyvirus infection were not observed despite examining several sections of embedded tissues.

Serology. The polyclonal antibodies raised against the purified virions of the two isolates detected SPCFV in infected sweet potato as well as in test plant species at a sap dilution of $1: 16,400$. In DAS-ELISA using different dilutions of coating IgG and AP-labeled IgG for sensitive detection, the optimal dilutions of coating IgG and APlabeled IgG were both 1:1000, indicating that the antiserum produced is highly virus specific. Even when higher concentrations of coating IgG and the AP-labeled IgG were used, host-specific reactions were not observed. In decoration tests, all particles of the Hoima 4 isolate were strongly decorated when incubated with its homologous antiserum (Fig. 3) but more variably by the heterologous antiserum to TN340 and the previously produced antiserum to SPCFVCIP, the type isolate (not shown).

Sequence variability in the 3 '-terminal genomic region of SPCFV. The

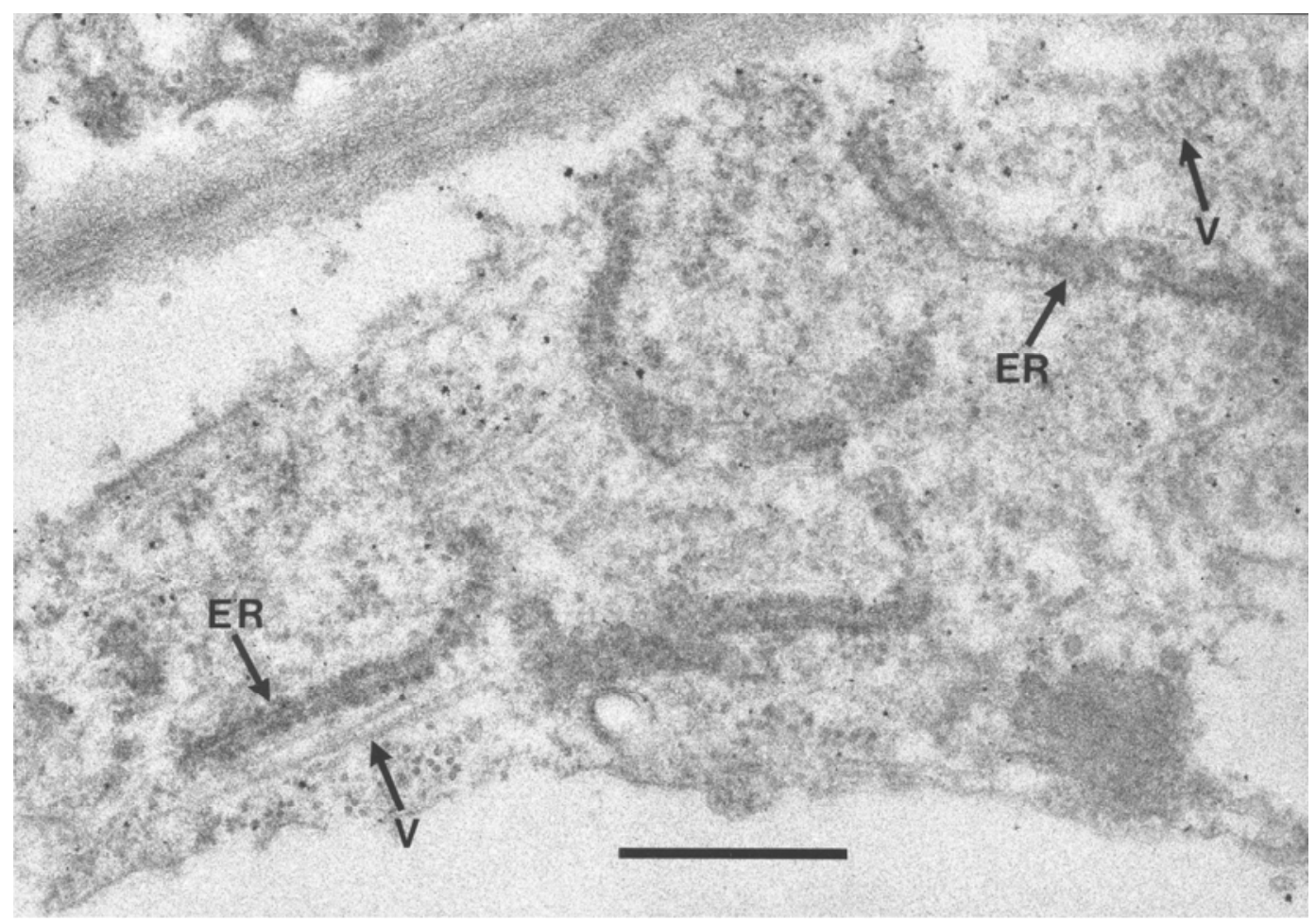

Fig. 2. Distorted and enlarged endoplasmic reticulum (ER) as major cytopathologic alterations in leaf parenchyma cells of Sweet potato chlorotic fleck virus (SPCFV)-infected Nicotiana occidentalis subsp. obliqua. Longitudinal and cross sections of SPCFV virions are indicated (V). Scale bar represents about $500 \mathrm{~nm}$. 
primer combination SPCFVuniUp1/ oligo(dT) $)_{18}$ amplified a 1,761-bp fragment from the 3'-proximal ends of 11 of the 15 SPCFV isolates from which partial sequences were obtained in this study. It failed, however, to amplify fragments from isolates TN340, 007VIIMS, and KY5; therefore, additional primers were designed for these three isolates (Table 2) based on the sequences of isolate Hoima 4, or the Random-PCR approach was used. Use of these primers allowed determination of the complete $3^{\prime}$ end of the RNAs of KY5, TN340, and 007VIIMS. The sequences generated from this study have been deposited in the GenBank/EMBL/ DDBJ database (for accession numbers, see Table 1). The nucleotide and amino acid sequences of the complete CP (900 nucleotides [nt], 300 amino acids [aa]) and nucleic acid binding protein (NaBP; ORF 6, $399 \mathrm{nt}, 133$ aa) and the nucleotide sequences of the intergenic region (IGR; $234 \mathrm{nt})$ preceding the $\mathrm{CP}$ and the $3^{\prime}$ untranslated region ( $\left.3^{\prime}-\mathrm{UTR} ; 55 \mathrm{nt}\right)$ formed the basis for comparing the 17 SPCFV isolates. The data revealed that SPCFV isolates are highly variable, with nucleotide and amino acid sequence identities ranging from 75.1 to 99.3 and 88.3 to $99.7 \%$, respectively, for the $\mathrm{CP}$ gene, and from 77.4 to 99.5 and 75.9 to $99.2 \%$, respectively, for the NaBP gene. Further examination revealed that two thirds of a total of 63 variable amino acid positions in the $\mathrm{CP}$ were located at the $\mathrm{N}$ terminus, whereas the 47 variable amino acid positions of the NaBP were equally distributed over the whole protein sequence.

The CP amino acid sequences of isolates from East Africa (EA) were similar to each other (94.0 to $99.7 \%$ identity). SPCFV-CIP, the type isolate of SPCFV, was also closely related (about 99\% amino acid identity) to the EA isolates (data not shown). Isolates Guangzhou 1 from China, and Le-97-589 and TN399, both of unknown origins, were intermediary $(90.6$ to $96.7 \%)$ in their amino acid sequence identities to each other and to the other isolates. Isolate TN340 from Taiwan and 008VIIMS of unknown origin were the least related to the other isolates ( $<80 \%$ amino acid identity) but were fairly close to each other $(96.3 \%$ amino acid identity).

There was also a high degree of variability among the SPCFV isolates in their IGR sequences, ranging from 60 to $99.1 \%$ identity. The isolates from Uganda were most similar not only to each other ( $>89.7 \%$ identity) but also to the isolate Tar from Tanzania, the type isolate SPCFV-CIP, and isolate $91 / 1 \mathrm{~S}$ from Kenya ( $>87.1 \%$ identity). The remaining isolates differed from them and from each other, with identities in the range of 60.1 to $66.5 \%$.

The 3'-UTR was nearly identical in the SPCFV isolates analyzed. The Ugandan isolates (with the exception of KBL38)
SPCFV-CIP and 94/1S varied by only one base change (data not shown). The rest of the isolates each had between 1 and 7 base substitutions, with TN340 and 007VIIMS showing the highest numbers of base exchanges.

Phylogenetic analysis. Phylogenetic analysis of the CP nucleotide sequences separated the 17 SPCFV isolates into geographically associated clusters (Fig. 4). A monophyletic group was formed by isolates from Uganda, Kenya, and Tanzania. The isolate Guangzhou 1 from China and isolate Le-97-589 of unknown origin grouped together, although they differed from each other in $\mathrm{CP}$ nucleotide sequence identity by about $12 \%$. Isolate TN399 of unknown origin seemed unique because it branched distantly from the rest of the isolates. Genetically, even more distant but branching as a single clade, were isolates TN340 from Taiwan and 007VIIMS of unknown origin. These isolates appeared to have the least relationship to other isolates. Within the East African monophyletic group, two subclusters appeared to be related to their geographic origin. Subcluster Ia was composed of Ugandan isolates, isolate 91/1S from Kenya, and SPCFV-CIP, the type isolate. Within this subcluster, isolate Rukingiri 1a, however, branched separately and appeared to be distinct from other isolates. Subcluster $\mathrm{Ib}$ was composed of two very similar Kenyan isolates.
The phylogenetic trees generated from algorithms from the NaBP protein and IGR (data not shown) had topologies largely similar to that of the $\mathrm{CP}$ sequences.

\section{DISCUSSION}

Although complete nucleotide sequencing of a Ugandan isolate of SPCFV had shown that it is member of Carlavirus (4), this virus was not formally described before. Therefore, we not only studied here its host range and serological and cytopathological properties but also compared the 3 -terminal regions of a geographically diverse range of SPCFV isolates.

SPCFV infected a limited number of plants in the families Convolvulaceae, Chenopodiaceae, and Solanaceae (Table 3) $(7,15)$. The few symptoms in its natural host and its narrow host range are similar to that of other carlaviruses. Of the about 40 definitive and about 30 tentative members of the genus Carlavirus, 21 are reported to infect plant species of not more than three families $(1,2)$.

SPCFV had particles with a normal length of $800 \mathrm{~nm}$, being longer than those of typical carlaviruses (610 to $700 \mathrm{~nm} ; 1,2)$ and more similar to those of potyviruses. However, no pinwheel inclusions typical of Potyvirus infections $(11,12)$ were detected. The observed cytopathological features resembled those of carlaviruses, including the limited number of virions in infected tissues $(1,2)$ and the very limited cytopathological effects apart from an

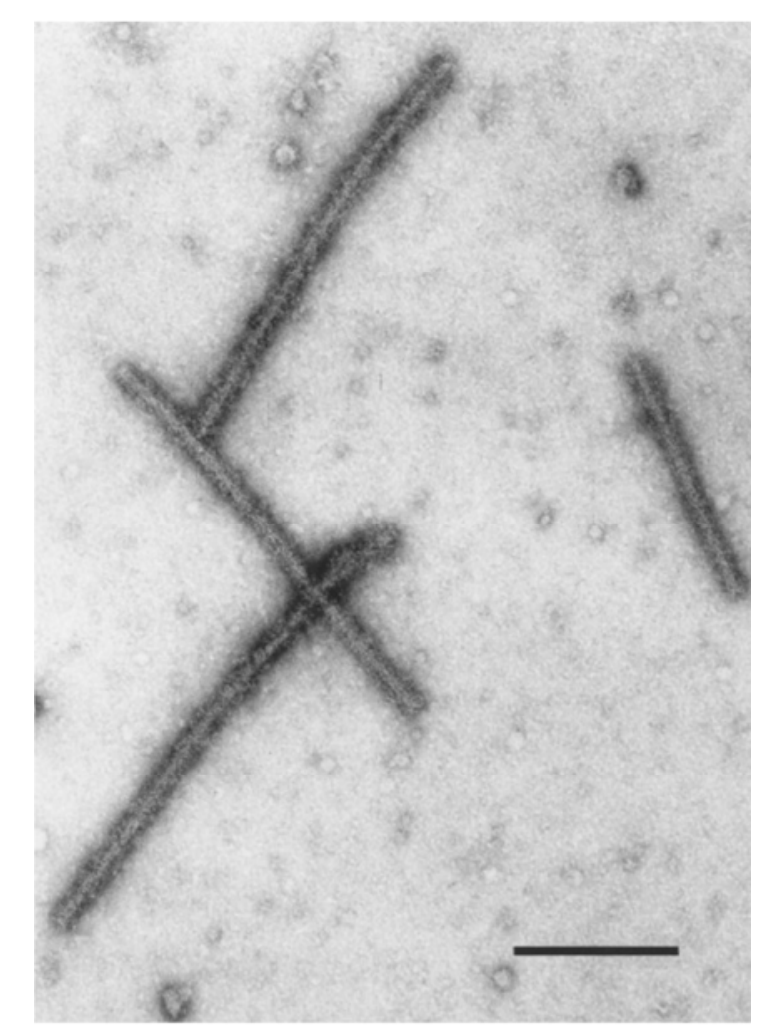

Fig. 3. Use of a Sweet potato chlorotic fleck virus (SPCFV) antiserum for immunoelectron microscopy decoration of SPCFV particles. Virions of isolate Hoima 4 strongly decorated with antibodies of the Hoima 4 antiserum. Scale bar represents about $300 \mathrm{~nm}$. 
enlarged and distorted endoplasmic reticulum.

Electrophoretic characteristics of SPCFV were also consistent with it being a member of Carlavirus. A single protein band of about $33 \mathrm{kDa}$ was observed in SDS-PAGE. This size is similar to previous estimates $(4,15)$ and falls within the range (31 to 36 $\mathrm{kDa}$ ) obtained for other carlaviruses $(1,2)$. During SPCFV purification, the $\mathrm{CsCl}$ gradients formed one major and a minor band above and below the virus band. This is similar to the formation of three bands described for a Cowpea mild mottle virus isolate by Antignus and Cohen (3), who suggested that the minor bands might result from conformational changes brought about by $\mathrm{CsCl}$.

The analyses done here on about 1,700 3 '-terminal nucleotides encompassing the complete ORF5 (CP), ORF6, and 3'-UTR of 17 SPCFV isolates provide the first data on the genetic variability of this virus. The $\mathrm{CP}$ amino acid sequence identities among the 17 SPCFV isolates varied widely, ranging from 88.3 to $99.7 \%$. This pattern of variation is repeated in ORF6 and IGR sequences preceding the putative $\mathrm{CP}$ gene.
Similar levels of sequence variations have been observed for other carlaviruses, such as Daphne virus $S$ (20), Lily symptomless virus (9), and Hop latent virus (16). A variability of even up to $81 \%$ in nucleotide sequence was documented when ordinary, Andean, and central European isolates of Potato virus $S$ (PVS) were compared using the C-terminal part of the replicase, the $\mathrm{CP}$, and the $11-\mathrm{kDa}$ proteins $(13,22)$. Due to this variability, isolate-specific primers were used to generate various regions of the PSV isolates (22); a similar situation was experienced in this study, where a successful amplification of the 3'-terminal regions of isolates KY5, TN340, and 007VIIMS was only possible with specific primers to each (Table 2). The sequence variability observed here for SPCFV seems characteristic of members of the genus Carlavirus.

Phylogenetic analysis clustered the isolates into groups that correlated with their geographic origins. One major monophyletic cluster represented by East African isolates and SPCFV-CIP was formed. The rest of the isolates formed various clusters separated from other isolates by large genetic distances. The distant relatedness among isolates outside East Africa suggests that SPCSV isolates are genetically diverse and that many more lineages will be revealed if more isolates from other countries are analyzed. Because the variability observed between the two genogroups of SPCFV isolates is based on differences at specific base positions, prospects of developing a rapid, nucleic acidbased detection technique are good. In preliminary studies on this specific aspect, the primer combination Hoima4TGBup1 (CGAAGGAGGCTGATACAATG)/oligo $(\mathrm{dT})_{18}$ amplified an approximately $1,300-$ bp product from the $3^{\prime}$-proximal end of all isolates in genogroup I but not from those of genogroup II. However, further research is required to screen for specificity and sensitivity of the primer combination. The genetic differences observed between these two genogroups may also result in different symptoms in different indicator plants but this has not yet been studied. They may also differ in pathogenicity in sweet potato but it has not yet been determined even whether any isolates of SPCFV affect crop yields.
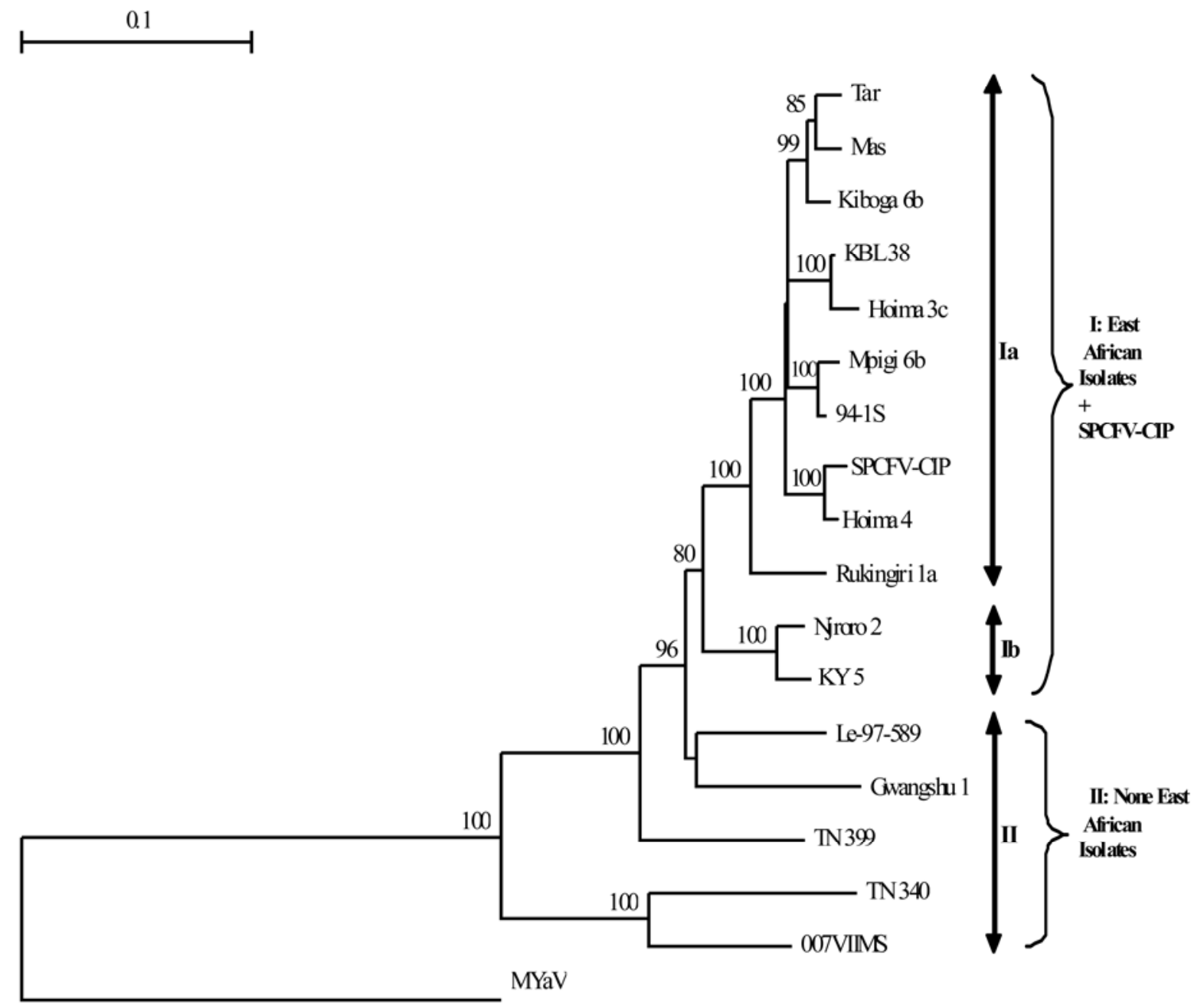

Fig. 4. Rooted phylogenetic trees of coat protein gene nucleotide sequences of 17 isolates of Sweet potato chlorotic fleck virus (SPCFV). See text for details on the construction of the phylogenetic trees. Bootstrap values are expressed as a percentage of 1,000 replicates. Branch lengths are proportional to genetic distances. 


\section{ACKNOWLEDGMENTS}

This article forms part of a Ph.D. thesis by V. Aritua. The research was supported by a grant from the European Union (ICA4-CT-2000-30007). We thank E. Ateka (Kenyata University of Agriculture and Technology, Nairobi, Kenya), L. F. Salazar (CIP, Lima, Peru), S. Winter (German Collection of Micoorganisms and Tissue Culture, Braunschweig, Germany), S. K. Green (Asian Vegetable Research and Development Center, Shanhua, Taiwan), and D. Colinet (formerly at University of Gembloux, Belgium) for providing sweet potato material containing SPCFV isolates.

\section{LITERATURE CITED}

1. Adams, M. J., Accotto, G. P., Agranovsky, A. A., Bar-Joseph, M., Boscia, D., Brunt, A. A., Candresse, T., Coutts, R. H. A., Dolja, V. V., Falk, B. W., Foster, G. D., Gonsalves, D., Jelkmann, W., Karasev, A., Martelli, G. P., Mawassi, M., Milne, R. G., Minafra, A., Namba, S., Rowhani, A., Vetten, H. J., Vishnichenko, V. K., Wisler, G. C., Yoshikawa, N., and Zavriev, S. K. 2005. Family Flexiviridae. Pages 1089-1124 in: Virus Taxonomy: Classification and Nomenclature of Viruses. Eighth Report of the International Committee on Taxonomy of Viruses. C. M. Fauquet, M. A. Mayo, J. Maniloff, U. Desselberger, and L. A. Ball, eds. Elsevier/Academic Press, Oxford.

2. Adams, M. J., Antoniw, J. F., Bar-Joseph, M., Brunt, A. A., Candresse, T., Foster, G. D., Martelli, G. P., Milne, R. G., Zavriev, S. K., and Fauquet, C. M. 2004. The new plant virus family Flexiviridae and assessment of molecular criteria for species demarcation. Arch. Virol. 149:1045-1060.

3. Antignus, Y., and Cohen, S. 1987. Purification and some properties of a new strain of cowpea mild mottle virus in Israel. Ann. Appl. Biol. 110:563-569

4. Aritua, V., Barg, E., Gibson, R. W., Adipala, E., and Vetten, H. J. 2007. Sequence analysis of the entire RNA genome of sweet potato chlorotic fleck virus reveals that it belongs to a distinct carlavirus species. Arch. Virol. 152:813-818.

5. Aritua, V., Bua, B., Barg, E., Vetten, H. J., Adipala, E., and Gibson, R. W. 2007. Incidence of five viruses infecting sweet potatoes in Uganda; the first evidence of Sweet potato caulimo-like virus in Africa. Plant Pathol. 56:324-331.

6. Ateka, E. M., Njeru, R. W., Kibaru, A. G., Ki- menju, J. W., Barg, E., Gibson, R. W., and Vetten, H. J. 2004. Identification and distribution of viruses infecting sweet potato in Kenya. Ann. Appl. Biol. 144:371-379.

7. CIP. 1991. International Potato Center Annual Report 1991. CIP, Lima, Peru.

8. CIP. 1992. International Potato Center Annual Report 1992. CIP, Lima, Peru.

9. Choi, A., and Ryu, K. H. 2003. The complete nucleotide sequence of the genome RNA of Lily symptomless virus and its comparison with that of other carlaviruses. Arch. Virol. 148:1943-1955

10. Clark, M. F., and Adams, N. 1977. Characteristics of the microtitre plate method of the enzyme-linked immunosorbent assay (ELISA) for the detection of plant viruses. J. Gen. Virol. $34: 475-483$.

11. Edwardson, J. R. 1974. Some properties of the potato virus Y-group. Florida Agricultural Experiment Station Monograph Series No. 4

12. Edwardson, J. R., and Christie, R. G. 1996. Cylindrical Inclusions. Page 79 in: University of Florida Agricultural Experiment Station Bulletin 874.

13. Foster, G. D., and Mills, P. R. 1991. Occurrence of chloroplast ribosome recognition sites within conserved elements of the RNA genomes of carlaviruses. FEBS Lett. 280:341343.

14. Froussard, P. 1992. A random PCR method (rPCR) to construct whole cDNA library from low amounts of RNA. Nucleic Acids Res. 20:2900.

15. Fuentes, S., and Salazar, L. F. 1992. Identification of a new sweet potato virus. Fitopatologia 27:50.

16. Hataya, T., Arimoto, R., Suda, N., and Uyeda, I. 2001. Molecular characterization of hop mosaic virus: its serological and molecular relationship to hop latent virus. Arch. Virol. 146:1935-1948

17. Higgins, D. G., Bleasby, A. J., and Fuchs, R. 1992. CLUSTAL V: improved software for multiple sequence alignment. Comp. Appl. Biosci. (CABIOS) 8:189-191.

18. Jukes, T. H., and Cantor, C. R. 1969. Evolution of protein molecules. Pages 21-132 in: Mammalian Protein Metabolism. H. N. Munro, ed. Academic Press, New York.

19. Koenig, R., and Lesemann, D.-E. 1985. Plant viruses in German rivers and lakes. Phytopathol. Z. 112:105-116.

20. Lee, B. Y., Min, B. E., Ha, J. H., Lee, M.Y., Paek, K. H., and Ryu, K. H. 2005. Genome structure and complete sequence of genomic RNA of Daphne virus S. Arch. Virol. 151:193200.

21. Mackenzie, D. J., McLean, M. A., Mukerji, S. and Green, M., 1997. Improved RNA extraction from woody plants for the detection of viral pathogens by reverse transcription-polymerase chain reaction. Plant Dis. 81:222-226.

22. Matoušek, J., Schubert J., D di, P., and Ptá ek, J. 2000. A broad variability of Potato virus $S$ (PVS) revealed by reverse transcriptase-polymerase chain reaction. Can. J. Plant Pathol. 22:29-37.

23. Milne, R. G., and Lesemann, D.-E. 1984 Immunosorbent electron microscopy in plant virus studies. Pages 85-101 in: Methods in Virology, vol. VIII. K. Maramorosch and H. Koprowski, eds. Academic Press, New York and London.

24. Mukasa, S. B., Rubaihayo, P. R., and Valkonen, J. P. T. 2003. Incidence of viruses and viruslike diseases of sweetpotato in Uganda. Plant Dis. 87:329-335.

25. Nagata, T., Alves, D. M. T., Inoue-Nagata, A. K., Tian, T.-Y., Kitajima, E. W., Cardoso, J. E. and de Avila, A. C. 2005. A novel melon flexivirus transmitted by whitefly. Arch Virol. 150:379-387.

26. Noordam, D. 1973. Identification of Plant Viruses, Methods and Experiments. Centre for Agricultural Publishing and Documentation, Wageningen, The Netherlands.

27. Rott, M. E., and Jelkmann, W. 2001. Characterisation and detection of several filamentous viruses of cherry: adaptation of an alternative cloning method (DOP-PCR), and modification of an RNA extraction protocol. Eur. J. Phytopathol. 107:411-420.

28. Salazar, L. F., and Fuentes, S. 2000. Current knowledge on major virus diseases of sweet potato. Pages 14-19 in: Int. Workshop Sweetpotato Cultivar Decline Study. Kyushu National Agricultural Experiment Station, Miyakonojo, Miyazaki, Japan.

29. Tairo, F., Kullaya, A., and Valkonen, J. P. T. 2004. Incidence of viruses infecting sweetpotato in Tanzania. Plant Dis. 88:916-920.

30. Van de Peer, Y., and De Wachter, R. 1993 TREECON: a software package for the construction and drawing of evolutionary trees Comp. Appl. Biosci. 9:177-182.

31. Vetten, H. J., Green, S. K., and Lesemann, D.E. 1992. Characterization of peanut stripe virus isolates from soybean in Taiwan. J. Phytopathol. 135:107-124. 